\title{
IJPHN
}

\section{Associations of Dietary Diversity and Other Factors with Prevalence of Stunting among Children Aged 6-35 Months}

\author{
Kelvin Halim ${ }^{1}$, Ratu Ayu Dewi Sartika ${ }^{2}$, Trini Sudiarti ${ }^{2}$, Primasti Nuryandari Putri ${ }^{2}$, Nurul Dina \\ Rahmawati $^{2}$ \\ ${ }^{1}$ Undergraduate Student of Public Health Nutrition Department, Universitas Indonesia, Depok, West Java, \\ Indonesia \\ ${ }^{2}$ Depatment of Public Health Nutrition, Faculty of Public Health, Universitas Indonesia, F Building $2^{\text {nd }}$ \\ Floor Kampus Baru UI Depok 16424, Indonesia \\ Corresponding author: ratuayu.fkm.ui@gmail.com
}

\begin{abstract}
Prevalence of stunting among under five children in Indonesia is still considered as a public health problem. Dietary diversity, one of the important assessments in infant and child feeding practice, is one of important determinants of stunting. This study is aimed to examine associations between dietary diversity with other factors with prevalence of stunting in Babakan Madang District, Bogor Regency in 2019. A cross-sectional design study was performed in this study during April-June in 2019. A total of 149 children's height aged 635 months was measured and defined based on WHO growth standards. Dietary diversity scores were collected from 24-hour food recall based on 7 food groups. Results showed that the prevalence of stunting in this study was $32.2 \%$ and $31.5 \%$ of them had low dietary diversity. There was association between dietary diversity and minimum acceptable diet with stunting $(\mathrm{p}$-value $=0.033$ and 0.013 ). Therefore, interventions should be taken by improving dietary diversity to reduce the burden and prevalence of stunting in both household and community level.
\end{abstract}

Keywords: dietary diversity; stunting; children aged 6-35 months

\begin{abstract}
Abstrak
Prevalensi stunting pada balita di Indonesia masih merupakan masalah kesehatan masyarakat. Keragaman pola makan sebagai salah satu asesmen penting dalampraktik pemberian makan bayi dan anak, merupakan salah satu determinan penting untuk stunting. Penelitian ini bertujuan untuk mengetahui hubungan antara keragaman pola makan dan faktor lain terhadap prevalensi stunting di Kecamatan Babakan Madang Kabupaten Bogortahun 2019. Studi cross sectional dilakukan pada penelitian ini selama bulan April -Juni tahun 2019. Sebanyak 149 anak usia 6-35 bulan diukur tinggi badannya dan didefinisikan menggunakan standar pertumbuhan tinggi badan menurut usia dari WHO. Skor keragaman pangan dikumpulkan dari Food Recall 24 jam berdasarkan 7 kelompok pangan. Hasil penelitian menunjukkan prevalensi stunting pada penelitian ini sebesar 32,2\% dan sebanyak 31.5\%-nya memiliki keragaman pola makan rendah. Terdapat hubungan antara keragaman diet dan asupan minimum yang dapat diterima dengan stunting ( $p$ value $=0.033$ dan 0.013). Dengan demikian, intervensi harus dilakukan dengan meningkatkan keragaman pangan untuk mengurangi beban dan prevalensi stunting baik di tingkat rumah tangga ma upun masyarakat.
\end{abstract}

Kata kunci: keanekaragaman makanan; stunting; anak usia 6-35 bulan.

\section{Introduction}

Stunting is still considered as one of the major problems in child malnutrition, especially in children under 5-years old (1). Stunting increases risk of health problems in the future such as infectious diseases, delayed cognitive development, and degenerative diseases $(2,3)$. Nearly $30 \%$ of under 5 children in Indonesia are stunted, even though it was decreasing during the last five years. To tackle this, Indonesian Government selected first 100 prioritized cities for stunting interventions focus location, including Bogor City.

Adequate linear growth and development during conception until 2 years of life are important (4). According to Barker's (1993) theory (5), that 
malnourished children since they are in the womb will increase the risk of becoming obese and experiencing noncommunicable diseases in adulthood compared to normal toddlers. Dietary diversity is not only important for a child starting from they reach 6 months, but also important since they are in the womb by taking into account balanced nutrition in the fulfilment status of macro and micronutrients in pregnant women. Thus, children must receive proper nutrition and health to optimize growth, development and prevent nutrition problem, including stunting. One of the main causes of stunting in children is inadequate both quantity and quality of dietary intake, in a long term period (5). It could be related to household food insecurity and poor child feeding practices. Dietary diversity is one of the ways to assess the quality of dietary intake, alongside with meal frequency, minimum acceptable diet, breastfeeding, and others. Dietary diversity can express diverse nutrient given to the children (6). Dietary diversity itself is associated and correlated nutrient adequacy, especially in micronutrients and protein, which is associated with dietary intake and stunting (7). Higher dietary diversity has been negatively associated with stunting and other under-nutrition status. Around $40 \%$ of children in Indonesia have not met minimum dietary diversity (3). Thus, this study aimed to examine associations between dietary diversity and other factors with stunting in children aged 6-35 months. The objectives of the study were to find the prevalence of stunting among children aged 6-35 months and its association with dietary diversity and other factors.

\section{Method}

This community-based crosssectional quantitative study was performed during April-May 2019 in
Babakan Madang District, Bogor Regency. The study population consisted of children aged 6-35 years old and their mothers/caregivers selected from 6 of 9 sub-districts chosen by cluster sampling technique. A total of 149 mother-child pairs participated in this study. Data of length/height's child were collected and measured by well trained enumerators, using a digital infant meter and microtoise with a precision of $0.1 \mathrm{~cm}$. Length/height data were then categorized using WHO Child Growth Standards.

Statistical analysis was supported by IBM SPSS statistics 16 with a license from Public Health Faculty Universitas Indonesia, with descriptive analysis and the relationship of independent variables with the incidence of stunting using chisquare for bivariate analysis. Values were deemed to be statistically significant when $p<0.1$. Anthropometric $Z$-scores were calculated using WHO-Anthro; Length/Height $\mathrm{z}$ scores were then classified as stunting with <-2 SD and $\geq-1.999$ as normal. Intake from 24-hours recall questionnaire and semi quantitative FFQ (Food Frequency Questionnaire) were interpreted using Household Dietary Diversity Score (HDDS) questionnaire to analyze food adequacy. DDS was based on 7 food groups, namely; 1) grains or staples, 2) flesh food (meat, poultry, fish, and organ meat), 3) eggs, 4) pulses or legumes or nuts, 5) vitamin-A-rich fruits and vegetables, 6) other fruits and vegetables, and 7) dairy products that were then categorized as low ( $<4$ food groups) and high $(\geq 4$ food groups).

The independent variables of social demographics were: family income, mother's education, children gender, history of infectious disease, frequently visiting to integrated services (posyandu), and birth weight. 


\section{Result}

This study included 149 children aged 6-35 months in 6 sub-districts of Babakan Madang District, Bogor high school or above. Most of the child's family in this study $(69.8 \%)$ also received income in below regional minimum wage (IDR 3,760,000) (Table 1).

Table 2 showed that $32.2 \%$ of children were stunted, and only $31.5 \%$ of the children had met minimum dietary diversity based on 7 food groups. Most of the children had met their minimum meal frequency. Combining dietary diversity and meal frequency, only $21.5 \%$ of children had achieved minimum acceptable diet. $90.6 \%$ of the children also had met minimum meal frequency. Almost all of the children
Regency. $34.9 \%$ of children were within the age group 6-11 months old. Only about one fourth of mother has attained $(89.3 \%)$ had history of infectious disease within 3 months, such as upper respiratory tract infection/URTI and diarrhea (Table 2).

According to bivariate analyses, results showed that there is significant association between dietary diversity and stunting $\quad(\mathrm{p}=0.033, \quad \mathrm{OR}=2.61, \quad 95 \%$ $\mathrm{CI}=1.14-5.99)$. Children with low dietary diversity have 2.61 times higher odds of having stunting compared with children with adequate dietary diversity. This study found another significant association between minimum acceptable diet and stunting $(\mathrm{p}=0.013$, $\mathrm{OR}=4.22,95 \% \mathrm{CI}=1.37-12.6)$ (Table 3$)$.

Table 1. Frequencies of children aged 6-35 months based on social characteristics

\begin{tabular}{ccc}
\hline \multirow{2}{*}{ Variables } & \multicolumn{2}{c}{$\mathbf{n = 1 4 9}$} \\
\cline { 2 - 3 } & $\mathrm{n}$ & $\%$ \\
\hline Age group (month) & & \\
$6-11$ & 52 & 34.9 \\
$12-23$ & 59 & 39.6 \\
$24-35$ & 38 & 25.5 \\
Biological sex & & \\
Male & 82 & 55.0 \\
Female & 67 & 45.0 \\
Mother's education level & \\
Low & 114 & 76.5 \\
High & 35 & 23.5 \\
Family income & & \\
Below minimum & 104 & 69.8 \\
Above minimum & 45 & 30.2 \\
\hline
\end{tabular}

\section{Discussion}

This study result showed that $32.2 \%$ of children aged 6-35 months are stunted, higher than national and province prevalence of stunting. WHO malnutrition classification also considered as high and critical (>30\%). Result showed the prevalence stunting is higher in age group of 24-35 month and males than other age group and females. This may occur due to higher nutrient requirement but same child feeding and diet in older age (1). Further analysis in this study found children in older age has 5-6 times higher risk of stunting than younger age (6-11 month).

\section{Dietary diversity and stunting}

This study showed the significant association between dietary diversity and stunting $\quad(\mathrm{p}=0.033 ; \quad 95 \% \quad \mathrm{CI}=1.14-5.99$; $\mathrm{OR}=2.61$ ). Children with less diverse diet have a 2.61 higher risk of stunting. Similar study in India found negative association between dietary diversity and stunting on children (6). Another study in Africa countries showed a good and adequate 
dietary diversity could give a better HAZ on children (7).

Dietary diversity is considerably a good assessment to describe good child feeding in quality. Dietary diversity ensures children is given diverse nutrients, both macronutrient and micronutrient.
Meeting minimum dietary diversity as suggested can assure children is given proper energy, protein, and other micronutrients such as vitamin A, vitamin $\mathrm{D}$, and iron (8). Both have important roles to achieve adequate linear growth and maintain nutritional status.

Table 2. Fre que ncies of nutritional s tatus, die tary dive rsity, and other factors among children aged 6-35 months

\begin{tabular}{|c|c|c|}
\hline Variables & $\begin{array}{l}\text { Frequency } \\
(n=149)\end{array}$ & Percentage \\
\hline \multicolumn{3}{|l|}{ Height-for-age (HAZ) } \\
\hline Stunted & 48 & 32.2 \\
\hline Not stunted & 101 & 67.8 \\
\hline \multicolumn{3}{|l|}{ Dietary diversity } \\
\hline Low $(<4$ groups $)$ & 102 & 68.5 \\
\hline High ( $\geq 4$ groups) & 47 & 31.5 \\
\hline \multicolumn{3}{|l|}{ Meal frequency } \\
\hline Not achieved & 14 & 9.4 \\
\hline Achieved & 135 & 90.6 \\
\hline \multicolumn{3}{|l|}{ Minimum aceptable diet } \\
\hline Not achieved & 117 & 78.5 \\
\hline Achieved & 32 & 21.5 \\
\hline \multicolumn{3}{|l|}{ Energy intake } \\
\hline Inadequate $(<90 \%)$ & 82 & 55.0 \\
\hline Adequat $(\geq 90 \%)$ & 67 & 45.0 \\
\hline \multicolumn{3}{|l|}{ Protein intake } \\
\hline Inadequate $(<90 \%)$ & 53 & 36.5 \\
\hline Adequat $(\geq 90 \%)$ & 96 & 63.5 \\
\hline \multicolumn{3}{|l|}{ Iron intake } \\
\hline Inadequate $(<77 \%)$ & 118 & 79.2 \\
\hline Adequat $(\geq 77 \%)$ & 31 & 20.8 \\
\hline \multicolumn{3}{|l|}{ History of infectious disease } \\
\hline Yes & 133 & 89.3 \\
\hline No & 16 & 10.7 \\
\hline \multicolumn{3}{|l|}{ Exclusive breastfeeding } \\
\hline Not exclusive & 81 & 54.4 \\
\hline Exclusive & 68 & 45.6 \\
\hline \multicolumn{3}{|c|}{$\begin{array}{l}\text { Frequently visiting to integrated services } \\
\text { (posyandu) }\end{array}$} \\
\hline Not routinely visit & 70 & 47.0 \\
\hline Routinely visit & 79 & 53.0 \\
\hline \multicolumn{3}{|l|}{ Vitamin A supplementation } \\
\hline Not given & 51 & 34.2 \\
\hline Given & 98 & 65.8 \\
\hline \multicolumn{3}{|l|}{ Birth weight } \\
\hline Low birth weight & 8 & 5.5 \\
\hline Normal birth weight & 137 & 94.5 \\
\hline
\end{tabular}


Table 3. Bivariate analyses and stunting among children aged 6-35 months

\begin{tabular}{|c|c|c|c|c|c|c|}
\hline \multirow{3}{*}{ Variable } & \multicolumn{4}{|c|}{ HAZ } & \multirow{3}{*}{ p-value } & \multirow{3}{*}{$\begin{array}{c}\text { OR } \\
(95 \% \mathrm{CI})\end{array}$} \\
\hline & \multicolumn{2}{|c|}{ Stunting } & \multicolumn{2}{|c|}{ Normal } & & \\
\hline & $\mathrm{n}$ & $\%$ & $\mathrm{n}$ & $\%$ & & \\
\hline \multicolumn{7}{|c|}{ Dietary diversity } \\
\hline Low & 39 & 38.2 & 63 & 61.8 & \multirow{2}{*}{$0.033 *$} & \multirow{2}{*}{$\begin{array}{c}\mathbf{2 . 6 1} \\
(1.14-5.99)\end{array}$} \\
\hline High & 9 & 19.1 & 38 & 80.9 & & \\
\hline \multicolumn{7}{|l|}{ Meal frequency } \\
\hline Not achieved & 4 & 28.6 & 10 & 71.4 & \multirow{2}{*}{0.995} & \multirow{2}{*}{$\begin{array}{c}0.83 \\
(0.25-2.79)\end{array}$} \\
\hline Achieved & 44 & 32.6 & 91 & 67.4 & & \\
\hline \multicolumn{7}{|c|}{ Minimum acceptable diet } \\
\hline Not achieved & 44 & 37.6 & 73 & 62.4 & \multirow{2}{*}{$\mathbf{0 . 0 1 3 *}$} & \multirow{2}{*}{$\begin{array}{c}\mathbf{4 . 2 2} \\
(1.37-12.6)\end{array}$} \\
\hline Achieved & 4 & 12.5 & 28 & 87.5 & & \\
\hline \multicolumn{7}{|l|}{ Energy intake } \\
\hline Inadequate & 22 & 26.8 & 60 & 73.2 & \multirow{2}{*}{0.168} & \multirow{2}{*}{$\begin{array}{c}0.58 \\
(0.29-1.16) \\
\end{array}$} \\
\hline Adequate & 26 & 38.8 & 41 & 61.2 & & \\
\hline \multicolumn{7}{|l|}{ Protein intake } \\
\hline Inadequate & 18 & 34.0 & 35 & 66.0 & \multirow{2}{*}{0.876} & \multirow{2}{*}{$\begin{array}{c}1.13 \\
(0.88-2.31)\end{array}$} \\
\hline Adequate & 30 & 30.3 & 66 & 69.7 & & \\
\hline \multicolumn{7}{|l|}{ Iron intake } \\
\hline Inadequate & 35 & 29.7 & 83 & 70.3 & \multirow{2}{*}{0.278} & \multirow{2}{*}{$\begin{array}{c}0.58 \\
(0.26-1.32)\end{array}$} \\
\hline Adequate & 13 & 41.9 & 18 & 58.1 & & \\
\hline \multicolumn{7}{|c|}{ History of infectious disease } \\
\hline Yes & 42 & 31.6 & 91 & 68.4 & 0845 & 0.77 \\
\hline No & 6 & 37.5 & 10 & 62.5 & 0.845 & $(0.26-2.26)$ \\
\hline Exclusive breas & eedir & & & & & \\
\hline Not exclusive & 27 & 32.1 & 54 & 67.9 & & 1.06 \\
\hline Exclusive & 21 & 30.9 & 47 & 69.1 & 0.932 & $(0.50-2.02)$ \\
\hline Integrated Ser & es P & (Posy & lu) $\mathrm{v}$ & & & \\
\hline Not routinely & 28 & 40.0 & 42 & 60.0 & & 1.97 \\
\hline Routinely & 20 & 25.3 & 59 & 74.7 & 0.082 & $(0.98-3.95)$ \\
\hline Vitamin A Sup & men & ion & & & & \\
\hline Not given & 11 & 21.6 & 40 & 78.4 & & 0.453 \\
\hline Given & 37 & 37.8 & 61 & 62.2 & 0.069 & $(0.21-1.00)$ \\
\hline Birth weight & & & & & & \\
\hline LBW & 5 & 62.5 & 3 & 37.5 & 0140 & 2.99 \\
\hline Normal BW & 49 & 35.8 & 88 & 64.2 & 0.149 & $(0.69-13.1)$ \\
\hline Mother's educa & & & & & & \\
\hline Low & 35 & 30.7 & 79 & 69.3 & & 0.75 \\
\hline High & 13 & 37.1 & 22 & 62.9 & 0.612 & $(0.34-1.66)$ \\
\hline Family income & & & & & & \\
\hline Below MRW & 37 & 35.6 & 67 & 64.4 & & 1.71 \\
\hline Above MRW & 11 & 24.4 & 34 & 75.6 & 0.253 & $(0.78-3.76)$ \\
\hline
\end{tabular}


Dietary diversity could describe not only food intake in quality, but also food intake in quantity, such as nutrient adequacy. An adequate nutrient adequacy could give a proper nutrient needs for development and linear growth10. Many studies confirmed significant association between DDS and nutrient adequacy, which also could describe food intake by quantity.

Studies in South Ethiopia and India suggested a medium to strong correlation between DDS and nutrient adequacies, particularly in protein and micronutrients such as iron, zinc, and vitamin B $(6,9)$. Further analysis in this study also found higher means of protein and iron intake adequacy percentages in children with high dietary diversity and also a medium correlation between nutrient adequacy and DDS $(9,10)$.

Proportion of children who haven't met minimum dietary diversity is higher in age group 6-11 month (88.5\%), rather than older age groups. Similar result also showed in national survey in Indonesia. In addition, a study in Madagascar also found children in younger age group, particularly in aged 6-11 months, had higher risk to have less dietary diversity (11). Complementary food is first introduced in children aged 6-11 month; hence they tend not to provide diverse diet and food, compared to children in older ages. Food recall analysis found children in younger age tend to be given 1-2 food groups in the previous day, i.e. baby instant oatmeal or porridge with vegetable broth. Less diverse dietary feeding in certain age group can influence macro and micronutrient diversity and intake (12). Further analysis in this study found significant association between children's age and dietary diversity given by their caregiver.

\section{Meal frequency and stunting}

This study showed no significant association between meal frequency and stunting $(p=0.995)$ that align with a study in countries in Africa and South Asia that also found no association between minimum meal frequency and lower risk of stunting $(13,14)$. Meal frequency counts any liquid, semi-solid, or solid food given to child, but does not count the density or volume of each meal frequency. Most of children who had met minimum meal frequency may often to be given less dense food, i.e. formula milk, biscuits, or snack foods. Children may achieve minimum meal frequency, but have not met daily energy requirement. Children may be given different meal frequency in different days, based on physiological or psychological condition of child while given food, or caregivers' efficacy to give certain food to children (9).

\section{Minimum acceptable diet and stunting}

This study showed significant association between dietary diversity and stunting $\quad(\mathrm{p}=0.013 ; \quad 95 \% \quad \mathrm{CI}=1.37-12.6$; $\mathrm{OR}=4.22$ ) where children who have not achieved minimum acceptable diet have a 4.22 higher risk of stunting. Similar study in Bangladesh found negative association between dietary diversity and stunting on children (17). Another study in Zambia showed children who met the minimum acceptable diet dietary diversity could have better linear growth (15).

Proper child feeding practice is one of the effective strategies to lower the risk of malnutrition and stunting, and thus to achieve a better linear growth and development. A good quality of child feeding can be described well in minimum acceptable diet by assessing children's dietary diversity and meal frequency $(16,17)$. Children who are unable to meet the minimum acceptable diet are likely to be given a less diverse diet and less energy-dense foods. An ideal child feeding quality can influence nutrient intake in children. Diverse diet and proper feeding frequency ensure children to achieve adequate amount and variety of nutrients for growth, which helps child's growth and development (11). 


\section{Conclusion}

This study showed a significant association between minimum acceptable diet and stunting. Providing food diversity in daily consumption in household, and community level is needed to prevent stunting. Governments in the health sector also have to take action such as giving awareness campaigns to mothers and pregnant women, and interventions aimed at the importance of child nutrition and proper child feeding practice with routine counseling in integrated services post (posyandu).

\section{Ethical Clearance}

Ethical clearance has been reviewed and released by Ethical Commitee of Faculty of Public Health, Indonesia, issued from May 6, 2019 (No. 257/UN2/F10/PPM.0002/2019).

\section{Conflict of Interest}

There is no conflict of interests.

\section{Acknowledgment}

The authors would like to thank for the research team and fellow other friends and partners helping this research. The authors also want to thank all the motherchild pairs who participated in this study and all parties in Babakan Madang District.

\section{References}

1. (WHO, UNICEF \& Group, 2018).World Health Organization. Child stunting: Prevalence of stunting in children under 5. (Online). cited February 8, 2019. Available from : http:/apps.who.int/gho/data/ node.sdg.2-2-viz-1 ?lang=en.

2. (de Onis and Branca, 2016). Childhood stunting: a global perspective. Maternal \& Child Nutrition, 2016, 12: 12-26.
3. (Victora et al., 2008). Maternal and child undernutrition: consequences for adult health and human capital. The Lancet, 2008; 371, 340-357.

4. (Achadi, EL. 2014). Kuliah Umum : Periode Kritis 1000 Hari Pertama Kehidupan dan Dampak Jangka Panjang terhadap Kesehatan dan Fungsinya. Yogyakarta: Persagi. https://docplayer.info/168456-

Periode-kritis-1000-hari-pertamakehidupan-dan-dampak-jangkapanjang-terhadap-kesehatan-danfungsinya.html

5. (Environmental et al., 2000) Barker, David JP., Osmond, Clive. (1993). 'Fetal, Infant, and Childhood Growth Are Predictors of Coronary Heart Disease, Diabetes, and Hypertension in Adult Men and Women'. MRC Environmental Epidemiology. Southampton General Hospital. University of Southampton. United Kindom.

6. (Aguayo et al., 2016). Determinants of stunting and poor linear growth in children under 2 years of age in India: an in-depth analysis of Maharashtra's comprehensive nutrition survey. Maternal \& Child Nutrition, 2016. 12: 121-140.

7. (Black, 2003). Operationalizing dietary diversity: a review of measurement issues and research priorities. 2003; 133(11):3911-26.

8. (UNICEF, 2012). Programming Guide: Infant and Young Child Feeding. New York: United Nations Children's Fund; 2012.

9. (Tegegne et al., 2017). Factors associated with minimal meal frequency and dietary diversity practices among infants and young children in the predominantly agrarian society of Bale zone, Southeast Ethiopia: a community based cross sectional study. Archives of Public Health; 75:53

10. (FAO, 2010). Kennedy, GL, Ballard T, \& Dop MC. Guidelines for Measuring 
Household and Individual Dietary Diversity. Roma: FAO.

11. (Rakotonirainy et al., 2018). Dietary diversity of 6- to 59-month-old children in rural areas of Moramanga and Morondava districts, Madagascar. PLoS One; 13(7).

12. (Issaka et al., 2015). Comparisons of complementary feeding indicators among children aged 6-23 months in Anglophone and Francophone West African countries. Maternal \& Child Nutrition; 11 Suppl 1:1-13.

13. (Altare et al., 2016). Factors Associated with Stunting among Preschool Children in Southern Highlands of Tanzania. Journal of Tropical Pediatrics; 62:390-408.

14. (Tessema, Belachew and Ersino, 2013). Feeding patterns and stunting during early childhood in rural communities of Sidama, South Ethiopia. Pan African Medical Journal; $14: 75$.

15. (Mallard et al., 2014). Dietary diversity at 6 months of age is associated with subsequent growth and mediates the effect of maternal education on infant growth in urban Zambia. The Journal of Nutrition; 2014; 14(11):1818-1825.

16. (Omaghomi Jemide et al., 2016). Association of maternal nutrition knowledge and child feeding practices with nutritional status of children in Calabar South Local Government Area, Cross River State, Nigeria. International Journal of Home Science; 2016; 2(1):293-98.

17. (Mya, Kyaw and Tun, 2019). Feeding practices and nutritional status of children age 6-23 months in Myanmar: A secondary analysis of the 2015-16 Demographic and Health Survey. PLoS One: 2019; 14(1): e0209044. 